\title{
TINJAUAN PENYIMPANAN SISTEM FIFO PADA BAHAN HEWANI YANG BERDAMPAK PADA PROSES PENGOLAHAN MAKANAN DI MORRISSEY HOTEL JAKARTA
}

\author{
Syaiful Tri Hadinata, Hendaris Adriyanto
}

Jakarta International Hotels School

\section{Article Information}

Received: 7 Oct. 2019

Accepted: 11 Mar. 2020

Published: 18 Apr. 2020

DOI 10.33555/ijembm.v6i2.100

Corresponding Author:

Hendaris Adriyanto

Jakarta, Indonesia

adriyantohak8@gmail.com

ISSN 2338-8854

eISSN 2620-9918

\begin{abstract}
This research focus on the implementing of the First In system First Out (FIFO) in the storage of animal-based foods which had impact on the food processing at the Morrissey Hotel Jakarta. Animal-based food has some different characteristics from other ingredients in the plant-based food. The processing is important because it can extend the expire date, increase durability, quality, value added and product diversification using the FIFO system. The research was done at the Morrissey Hotel in Jakarta. Data collection techniques was divided into two, namely primary data and secondary data. Primary data obtained with observational methods based on the facts in the hotel during the author do the internship, while secondary data obtained from literature studies such as books and electronic books and journals. Descriptive research results indicated that the system storage of animal-based foods at Morrissey Hotel Jakarta did not use the FIFO storage system so the food processing is hampered, and the process of storing animal-based food at the Hotel Morrissey Jakarta did not based on the type of animal groups which may cause damage in animal-based food and contaminated the other animal-based food.
\end{abstract}

Keywords: Animal-based Food, FIFO System, Food Processing

\begin{abstract}
ABSTRAK
Penelitian ini memiliki fokus masalah tentang penerapan sistem First In First Out (FIFO) pada penyimpanan bahan makanan hewani yang berdampak pada proses pengolahan makanan di Hotel Morrissey Jakarta. Bahan pangan hewani memiliki karakteristik yang berbeda dengan bahan pangan nabati, sehingga pengolahan penting karena dapat memperpanjang masa simpan, meningkatkan daya tahan, kualitas, nilai tambah dan sebagai sarana diverifikasi produk dengan menggunakan system FIFO. Penelitian ini dilakukan di Hotel Morrissey Jakarta. Teknik pengumpulan data dibagi menjadi dua, yaitu data primer dan data sekunder. Data primer didapatkan dengan metode observasi berdasarkan fakta yang ada di lapangan selama penulis melakukan praktik kerja lapangan, sedangkan data sekunder didapatkan dari studi kepustakaan seperti buku dan media elektronik seperti internet. Hasil penelitian deskriptif menunjukkan bahwa sistem penyimpanan bahan makanan hewani di Morrissey Hotel Jakarta tidak menjalankan sistem penyimpanan FIFO sehingga menyebabkan proses pengolahan makanan terhambat, dan proses penyimpanan bahan hewani di Hotel Morrissey Jakarta disimpan tidak berdasarkan jenis kelompok bahan hewani tersebut sehingga dapat menimbulkan kerusakan pada bahan hewani serta terkontaminasi dengan bahan hewani lainnya.
\end{abstract}

Keywords: Bahan Hewani, Sistem FIFO, Pengolahan Makanan 


\section{Pendahuluan}

Bahan pangan hewani merupakan bahanbahan makanan yang berasal dari hewan atau olahan yang bahan dasarnya dari hasil hewan. Kedua bahan pangan ini memiliki karakteristik yang berbeda sehingga memerlukan penanganan dan pengolahan yang berbeda pula. Bahan pangan hewani memiliki karakteristik yang berbeda dengan bahan pangan nabati. Bahan pangan hewani memiliki daya simpan yang jauh lebih pendek dari pada bahan pangan nabati bila dalam keadaan segar (kecuali telur). Bahan pangan hewani bersifat lunak sehingga mudah tertekan oleh faktor tekanan dari luar. Karakteristik masing-masing bahan pangan hewani sangat spesifik sehingga tidak bisa digeneralisasi. Sifat pada daging sangat berbeda dengan sifat telur.

Berbeda dengan pangan nabati yang memiliki kesamaan dalam hal jaringan atau komponenkomponen penyusunnya. Bahan pangan hewani pada umumnya merupakan sumber protein dan lemak, sedangkan bahan pangan nabati merupakan sumber karbohidrat, vitamin, mineral, lemak dan protein. Berdasarkan hal di atas maka pengolahan menjadi penting karena dapat memperpanjang masa simpan, meningkatkan daya tahan, meningkatkan kualitas, nilai tambah dan sebagai sarana diverifikasi produk. Dengan demikian, suatu produk menjadi memiliki daya ekonomi yang lebih setelah mendapat sentuhan teknologi pengolahan. First In First Out (FIFO) yaitu sistem yang biasa digunakan di bidang kuliner untuk penyimpanan bahan makanan, yang dapat diartikan bahan makanan yang pertama masuk ke dalam penyimpanan maka barang itu pula yang akan dikeluarkan jika ingin digunakan. Dengan begitu, tidak ada barang lama yang terbuang karena rusak. Fungsi sistem FIFO yaitu untuk meminimalisir kerugian kualitas barang di gudang agar barang yang disimpan tersebut nantinya tidak mengalami kerusakan dikarenakan barang terlalu lama tersimpan, sehingga dengan sistem FIFO ini alur pengeluaran barang menjadi teratur dan terkontrol. Berdasarkan latar belakang masalah yang telah dikemukakan sebelumnya, maka hal-hal yang dapat dijadikan identifikasi masalah antara lain:

a. Penerapan sistem FIFO pada penyimpanan bahan makanan hewani yang berdampak pada proses pengolahan makanan.

b. Klasifikasi bahan makanan hewani pada jenisnya masing-masing pada proses penyimpan.

Untuk menghindari terjadinya perluasan masalah, maka penulis membatasi permasalahan hanya sebatas tinjauan sistem penyimpanan FIFO pada bahan Hewani yang berdampak pada proses pengolahan makanan di Hotel Morrissey Jakarta.

\section{Tinjauan Pustaka}

\subsection{Definisi Penyimpanan Bahan Makanan}

Penyimpanan bahan makanan dan minuman adalah satu tata cara menata, menyimpan, memelihara bahan pangan kering dan basah, baik kualitas maupun kuantitas di gudang bahan makanan kering dan basah. Syarat penyimpanan bahan makanan yaitu menggunakan sistem First In First Out (FIFO) dan adanya tempat penyimpanan. (Astina, 2016). Menurut Spears (2009), "Ideally, the storage area should be on the same floor as the production area and visible to the food service manager". Artinya, area penyimpanan yang baik dapat dilihat oleh manajer jasa makanan dan berada di lantai yang sama dengan area produksi. Dengan melakukan hal ini makan pengamanan dalam penyimpanan bahan makanan lebih mudah dilakukan karena manajer dapat mengetahui siapa saja yang keluar-masuk area penyimpanan. 


\subsection{Definisi First In First Out (FIFO)}

Menurut Sudiara (2010) "metode ini adalah rotasi penyimpanan dan pengeluaran persediaan bahan makanan berdasarkan penerimaan yang terlebih dahulu diletakan paling depan atau di atas dari tempat penyimpanannya. Pada proses pengeluaran tersebut, didahulukan pada bahan makanan yang diterima terlebih dahulu. Pengawasan atau kontrol barang makanan dilakukan menggunakan kartu barang atau bincard yaitu kartu untuk mencatat jumlah barang makanan yang masuk dan keluar serta sisanya dan tangga terjadinya. Bahan makanan yang masuk terlebih dahulu akan digunakan terlebih dahulu pula sesuai dengan prinsip FIFO menurut Ninemeier (2009), "It is important that control procedure designed to minimized that lost of quatity of product in storage be strictly followed FIFO method that first in first out rotation. Rotation method is good rule. The product held inventory the largest should be the first to be issued to production area". Dalam terjemahan bebas, begitu pentingnya mengawasi prosedur yang ditetapkan untuk mengurangi kerugian kualitas produk dalam penyimpanan agar sesuai dengan aturannya. FIFO menerapkan sistem perputaran barang yang masuk pertama akan lebih dahulu dikeluarkan, dan merupakan suatu aturan yang baik.

\subsection{Definisi Bahan Hewani}

Bahan pangan hewani merupakan bahanbahan makanan yang berasal dari hewan meliputi susu, telur, daging, dan ikan serta produk-produk olahannya yang bahan dasarnya berasal dari hasil hewani (Astriani, 2010). Sejalan dengan teori diatas, bahan pangan hewani memiliki karakterisitik yang membedakan dengan bahan pangan nabati. Beberapa diantaranya adalah: (a) Bahan pangan hewani memiliki daya simpan yang jauh lebih pendek daripada bahan pangan nabati bila dalam keadaan segar (kecuali telur); (b) Bahan pangan hewani bersifat lunak dan lembek sehingga mudah terpenetrasi oleh faktor tekanan dari luar; (c) Karakteristik masing-masing bahan pangan hewani sangat spesifik sehingga tidak bisa digeneralisasi; (d) Bahan pangan hewani pada umunya merupakan sumber protein dan lemak, sedangkan bahan pangan nabati merupakan sumber karbohidrat, vitamin, mineral, lemak dan protein.

\subsection{Definisi Food and Beverage Depart- ment}

Food and beverage department adalah bagian yang bertanggungjawab mengelola makanan dan minuman yang disertai dengan pelayanan. Food and beverage department adalah salah satu struktur yang pasti ada dalam hotel berbintang, yang memiliki peran penting dalam mendapatkan revenue. Selain itu, food and beverage department juga berperan dalam menjaga reputasi melalui pelayanan terhadap tamu. Menurut Mertayasa (Food and Beverage operational 2012) yang dimaksud dengan food and beverage management adalah "bagian yang mempunyai tugas pokok untuk menyiapkan dan menyajikan makanan dan minuman kepada tamu baik di hotel maupun di luar hotel". Food and beverage department dibagi menjadi dua bagian yaitu: (a) Front service: bagian yang melakukan kontak langsung dengan tamu, terdiri dari restaurant, banquet, bar dan room service; (b) Back service: bagian yang tidak melakukan kontak langsung dengan tamu terdiri dari kitchen stewarding.

\subsection{Definisi Kitchen}

Dapur (kitchen) merupakan salah satu tempat yang dapat menghasilkan keuntungan yang besar kepada hotel karena di sanalah tempat terbuatnya suatu makanan yang akan menjadi salah satu daya tarik bagi tamu yang menginap ataupun tamu yang hanya sekedar ingin mencicipi makanan tersebut. Menurut 
Andrews (2013), "Kitchen is the place where food is prepared for cooked". Maksud dari kalimat tersebut adalah "dapur adalah tempat di mana makanan untuk di persiapkan untuk dimasak". Berdasarkan tugasnya dapur (kitchen) terbagi menjadi tiga bagian, yaitu cold kitchen, hot kitchen, dan pastry kitchen.

\subsection{Definisi Pengolahan Makanan}

Pengolahan makanan adalah serangkaian kegiatan dalam menangani makanan yang dimulai sejak pengadaan bahan makanan sampai penyajian makanan, dalam lima unsur yaitu tempat, orang, peralatan, makanan, metode proses pengolahan makanan (Sucipto, 2015). Memasak adalah sebuah cara mentransformasi bahan makanan menjadi sesuatu yang berbeda. Transformasi makanan pada umumnya memerlukan pemanas yang diperoleh dengan cara memindahkan energi dari sumber-sumber panas ke makanan, sehingga molekul yang terdapat pada makanan berubah cepat dan bereaksi ke bentuk dan struktur baru. Metode memasak dengan teknik merebus, mengukus dan menggoreng menunjukan ada perbedaan bentuk cara pemindahaan panas yaitu melalui perantara air, uap air dan minyak goreng (Mulyatiningsih, 2007).

\subsection{Definisi Penyimpanan Freezer}

Penyimpanan beku adalah penyimpanan dalam suasana suhu beku yang sangat rendah agar dapat mempertahankan semua faktor mutu yang diinginkan pada produk dengan daya awet sepanjang mungkin sesuai yang diinginkan dalam batas-batas daya dan biaya yang masih menguntungkan (Nur, 2013). Menurut Nur (2013), penyimpanan pada suhu $10^{\circ} \mathrm{C}$ sudah cukup baik karena pada suhu itu kegiatan mikrobiologi terhenti.

Cara penyimpanan produk beku di dalam cold storage juga harus mengikuti caracara yang baik dan terencana. Sebaiknya produk beku disimpan sesudah dikemas dengan baik, karton-karton atau peti disusun rapi sesuai dengan waktu pengolahannya. Sistem pengeluaran dan pemuatan produk beku dari dalam cold storage ke dalam container (peti kemas) hendaknya mengikuti sistem FIFO (First In First Out) sehingga tidak ada produk lama tersimpan dalam cold storage (Mulyanto, 1992).

\section{Metode Penelitian}

Metode pengumpulan data yang dilakukan adalah berdasarkan fakta yang didapat penulis selama menjalakan praktik kerja lapangan, yang kemudian data tersebut dianalisa dan dijelaskan dalam karya tulis akhir ini dari berbagai informasi yang dibutuhkan dalam pengerjaan dan penerapannya. Teknik pengumpulan data menggunakan: (a) Observasi: Data primer merupakan hasil pengamatan yang didapatkan oleh penulis pada saat menjalankan praktek kerja lapangan Kitchen: (b) Studi Kepustakaan: Data sekunder yang didapat dari buku, media elektronik seperti internet.

\section{Hasil dan Pembahasan}

\subsection{Belum Dilakukannya Sistem Penyimpanan FIFO pada Bahan Makanan Hewani yang Berdampak pada Proses Pengolahan}

Dalam sistem penyimpanan bahan makanan hewani di Hotel Morrissey Jakarta, tidak menjalankan sistem penyimpanan FIFO sehingga menyebabkan proses pengolahan makanan terhambat. Masalah yang sering terjadi ialah:

a. Proses Penyimpanan yang Salah

Hotel Morrissey tidak menjalankan penyimpanan yang baik dan benar. Mulai dari proses pengepakan yang hanya ditempatkan dengan tray dan tidak ditutup dengan rapat sehingga sangat mudah sekali tray terbuka dan akan tercampur dengan bahan hewani lainnya. Proses labeling di Hotel Morrissey Jakarta tidak dilakukan sehingga tidak dapat diketahui 
jenis bahan hewani dan waktu bahan hewani tersebut disimpan. Hal itu menyebab-kan banyak bahan hewani yang sangat mudah rusak akibat terkontaminasi oleh bahan lainnya. Selain itu, suhu penyimpanan yang tidak stabil mengakibatkan tidak bertahan lamanya bahan hewani pada proses penyim-panan.

b. Tidak Dijalankannya SOP (Standar Operasional Prosedur)

Tidak dilakukannya SOP pada proses penyimpanan bahan makanan hewani yang menggunakan sistem FIFO mengakibatkan bahan hewani tidak terkontrol, Hal ini terjadi karena kurangnya perhatian sous chef untuk memberikan pengarahan dan mengingatkan para kitchen staff untuk melakukan SOP.

\section{c. Perputaran Rotasi Menu Tidak Teratur dan Sering Terjadi Pengulangan}

Dikarenakan sistem penyimpanan FIFO tidak berjalan, sehingga stok dalam lemari penyimpanan bahan makanan hewani tidak terkontrol dan banyaknya bahan hewani yang rusak dikarenakan penyimpanan yang tidak benar. Hal itu menyebabkan bahan makanan hewani harus dibuang sehingga mengakibatkan stok tidak mencukupi dan hal ini tentu saja berpengaruh terhadap kelangsungan operasional di dalam kitchen di Hotel Morissey Jakarta. Berdasarkan data sebanyak $45 \%$ bahan hewani yang terbuang diakibatkan bahan hewani yang rusak, dan sebesar 55\% bahan hewani masih bisa digunakan untuk kegiatan proses pengolahan makanan. Faktor lain kurangnya bahan baku pada proses pengolahan antara lain: (a) Tercampurnya pemesanan A'la carte dan Buffeet: Bahan hewani antara a'la carte dan buffeet tidak dipisahkan sehingga bahan hewani yang telah disiapkan untuk buffet juga digunakan untuk pesanan a'la carte hal ini menjadikan kurangnya bahan untuk kegiatan operasional buffet ataupun sebaliknya; (b) Terlambatnya proses purchasing order karena kurangnya sehingga bahan baku tidak memadai untuk proses pengolahan makanan.

d. Mengubah Standar Rotasi Menu yang Telah Ditentukan

Hotel Morrissey Jakarta seringkali mengubah standar menu yang telah di tentukan dalam buku rotasi menu, sehingga terjadinya pengulangan menu yang mengakibatkan tamu complaint (keluhan) karena menu yang sama dalam satu hari atau berbeda satu hari. Hal itu dikarenakan bahan makanan hewani yang rusak sehingga para staff Hotel Morrissey Jakarta mengubah menu yang seharusnya sudah ditetapkan pada hari itu diubah menjadi menu untuk keesokan harinya ataupun lusa. Kejadian ini diakibatkan karena bahan hewani tidak mencukupi untuk rotasi menu pada hari itu, sehingga mencari rotasi menu di hari lain yang menggunakan bahan hewani lain yang tersisa dalam stok penyimpanan.

\subsection{Belum Terklasifikasinya Bahan Makanan Hewani pada Jenisnya Masing-Masing dalam Proses Penyimpanan}

Penyimpanan bahan hewani di Hotel Morrissey Jakarta tidak berdasarkan jenis kelompok bahan hewani tersebut sehingga bisa menimbulkan kerusakan pada bahan hewani dan menyebabkan bahan hewani akan terkontaminasi dengan bahan hewani lainnya. Faktor yang mengakibatkan tidak terklasifikasinya bahan makanan hewani yaitu:

a. Tempat Penyimpanan yang Kurang Memadai Mengakibatkan Proses Klasifikasi Bahan Hewani Tidak Berjalan

Salah satu yang mengakibatkan tidak berjalannya klasifikasi bahan makanan hewani yaitu tempat penyimpanan bahan hewani yang kurang memadai, sehingga bahan hewani hanya ditempatkan pada satu tempat penyimpanan lemari pembeku yang ukurannya kurang memadai untuk 
menyimpan berbagai macam bahan hewani, sehingga menyulitkan untuk melakukan kegiatan klasifikasi bahan makanan hewani karena bahan hewani yang telah tertumpuk.

\section{b. Mekanisme Kerja Para Karyawan dalam Kegiatan Operasional}

Cara kerja para karyawan yang terlalu terburu-buru saat kegiatan operasional dapur berjalan mengakibatkan proses klasifikasi bahan makanan saat penyimpanan terganggu. Para karyawan hanya fokus pada kegiatan pengolahan makanan, sehingga proses penyimpanan tidak dilakukan dengan benar dan bahan makanan hewani tidak diklasifikasikan berdasarkan jenisnya masing-masing. Hasil dari pegolahan makanan juga sering kali terlambat dari waktu yang sudah ditentukan untuk menghidangkan makanan, diakibatkan kerja para karyawan yang terburu-buru.

\section{Kesimpulan}

\subsection{Teridentifikasi Sistem Penyimpa-nan} FIFO pada Bahan Hewani Sehingga Berdampak pada Proses Pengolahan Makanan

Pada kesimpulan ini, sudah teridentifikasi sistem penyimpanan FIFO pada bahan hewani yang memiliki dampak pada proses pengolahan makanan. Penyimpanan yang baik dan menggunakan sistem FIFO sangatlah berpengaruh pada proses pengolahan makanan yang akan kita buat. Dalam penyimpanan bahan makanan yang mana tidak menggunakan sistem penyimpanan FIFO menyebabkan bahan hewani rusak sebelum proses pengolahan makanan dan juga hasil yang buruk dan tidak memuaskan seperti makanan memiliki bau yang tidak sedap diakibatkan tercampur dengan bahan hewani yang telah rusak. Dalam hal tersebut, kita harus menggunakan sistem penyimpanan yang baik yaitu sistem FIFO, jika tidak akan mengganggu operasional kerja di dalam dapur.

\subsection{Terklasifikasinya Bahan Makanan Hewani Berdasarkan Jenisnya pada Proses Penyimpanan}

Seorang juru masak juga harus mengetahui atau memiliki pengetahuan tentang penyimpanan bahan makanan hewani yang benar, sebab untuk menangani bahan makanan hewani haruslah menggunakan metode penyimpanan yang tepat agar bahan hewani tidak rusak dan terkontaminasi dengan bahan hewani lainnya. Kurangnya kepedulian atau perhatian yang penuh terhadap penanganan dan pengawasan oleh atasan dalam penyimpanan bahan hewani dapat menyebabkan kerusakan terhadap bahan hewani tersebut, karena pada dasarnya kerusakan yang terjadi dapat mengganggu proses operasional dapur yang sedang berlangsung.

\section{Daftar Pustaka}

Andrews, S. (2013). Food and Beverage a Training Manual, $3^{\text {rd }}$ Ed. New Delhi: McGraw-Hill.

Astina, I.B.K. (2016). Pengaruh Teknik Penyimpanan Bahan Baku Terhadap Kualitas Makanan dan Minuman Pada Departemen Food \& Beverage di Hotel Vila Shanti Sanur Bali. Denpasar: Universitas Udayana.

Astriani, C. (2010). Pengelompokan Bahan Hewani.

Mertayasa. (2012). Food and Beverage Service Operational. Yogyakarta: Andi.

Mulyatiningsih, E. (2007). Teknik-Teknik Dasar Memasak. Yogyakarta: Univesitas Negeri Yogyakarta.

Mulyanto. (2008). Penyimpanan Produk Beku dalam Cold Storage.

Nur, M. (2013). Kerusakan Selama Pembekuan dan Penyimpanan Beku pada Produk Perikanan. Available from: https://www.academia.edu /21576793/Kerusakan_selama_Pem 
YANG BERDAMPAK PADA PROSES PENGOLAHAN MAKANAN

DI MORRISSEY HOTEL JAKARTA

bekuan_dan_Penyimpanan_Beku_p

ada_Produk_Perikanan.

Sudiara. (2010). Pusat Pendidikan dan Latihan Pariwisata Dhyana Pura Pusat Pendidikan dan Latihan Pariwisata Dhyana Putra.

Sucipto, D.C. (2015). Keamanan Pangan

Untuk Kesehatan Manusia, $1^{\text {st }}$ Ed.

Yogyakarta: Gosyen. 